\title{
Lack of soil seedbank change with time since fire: relevance to seed supply after prescribed burns
}

\author{
Matthew P. Chick ${ }^{\mathrm{A}, \mathrm{B}}$, Janet S. Cohn ${ }^{\mathrm{A}}$, Craig R. Nitschke ${ }^{\mathrm{A}}$ and Alan York ${ }^{\mathrm{A}}$ \\ ${ }^{A}$ School of Ecosystem and Forest Sciences, University of Melbourne, 500 Yarra Boulevard, \\ Richmond, Vic. 3121, Australia. \\ ${ }^{B}$ Corresponding author. Email: mchick@student.unimelb.edu.au
}

\begin{abstract}
Soil seedbanks play a key role in the post-fire recruitment of many plant species. Seedbank diversity can be influenced by spatial variability (e.g. geographic location), environmental variability (e.g. soils) and temporal disturbance heterogeneity (e.g. time since fire, TSF) across the landscape. Unlike for aboveground vegetation, relationships between these factors and soil seedbank diversity remain largely unknown. Partitioning the influence of spatial and environmental variability from that of TSF, and explaining how these factors interact with seedbank diversity, will assist conservation managers in their application of prescribed burning. We germinated soil seedbank samples from sites ranging from 1 to 75 years since fire in a heathy-woodland ecosystem across the Otway Ranges in Victoria, Australia. We also measured spatial and environmental variability across sites to partition the influence of these variables and TSF on propagules available for recruitment. We found weak positive relationships between seedbank richness and TSF; however, these relationships varied across the landscape. We found composition did not change considerably over time, suggesting, in this ecosystem, pre-fire age is not strongly influencing propagules available for recruitment post-fire. Our results suggest that spatial and environmental variability influence seedbank composition more than TSF.
\end{abstract}

Additional keywords: biodiversity, fire management, heathy-woodland, time since fire.

Received 16 January 2015, accepted 8 August 2015, published online 1 October 2015

\section{Introduction}

Understanding how ecological diversity responds to disturbance is an important part of managing and conserving ecosystems (Levin and Paine 1974; Hall et al. 2012). The process of vegetation succession following disturbance is characterised by a sequence of changing plant communities over time (Kimmin 2004). Classic models of plant succession have described an early post-disturbance increase in species diversity as pioneer species recruit, a climax in the mature stages as species co-exist and a decrease thereafter as the shorter-lived species senesce (Connell 1978). However, empirical research indicates that this humped shape plant-succession-diversity relationship rarely occurs (Randall Hughes et al. 2007). In reality the relationship varies with ecosystem, region, disturbance type and disturbance severity, indicating that a single unified theory of succession in plant diversity is unlikely (Christensen 2014). Disturbance type and severity can influence subsequent plant-disturbanceregeneration trait responses (Bellingham and Sparrow 2000) and rates of ecosystem structure and competition process restoration (Keeley 2009). This variation has resulted in considerable debate regarding the merit of classic theories (Fox 2013), with models of plant-diversity-disturbance relationships becoming more complex, stochastic and region specific (Richards et al. 1999; Korovin et al. 2011).

Despite debate around the nature of the relationship between plant diversity and time since disturbance, forest managers worldwide are classifying and managing biodiversity in ecosystems based on developmental stages (Benkobi and Uresk 1996; Andison and Marshall 1999; Cheal 2010; Burrows and McCaw 2013). Known synonymously as successional, seral or growth stages, they are defined using the ecological characteristics of co-occurring vascular plant species. These characteristics include species developmental traits (time to reproductive maturity or mortality), functional and fire persistence traits, and relationships to regional physiographic variables (Cheal 2010).

Fire persistence traits in plants include re-sprouting from lignotubers or epicormic buds (termed re-sprouting), germinating solely from seeds banked in the soil or canopy (termed obligate seeding), or both in combination (termed facultative) (Noble and Slatyer 1980; Pausas et al. 2004). Soil-banked seed can be transient or persistent (Garwood 1989), leading to changes in composition and therefore propagules available for recruitment over time. Transience and persistence is influenced by life history traits, seed production, seed dormancy mechanism (Thompson and Ooi 2010), seed morphology and seed longevity (Auld et al. 2000), all of which are species specific. Seed produced early after disturbance can enter the soil profile and remain dormant but viable for many years (Livingston and Allessio 1968). This persistence is often related to seed size and shape (Garwood 1989), due to the higher burial probability of smaller seed with rain percolation into soil (Warr et al. 1993) or ant harvesting (Beaumont et al. 2011). Soils with higher water-holding capacity 
can stimulate germination of non-dormant seed while also speeding up the degradation of dormant seed in the soil (MorenoCasasola et al. 1994). Therefore, the physical and chemical properties of soil can directly affect the composition of propagules available at the time of disturbance (Warr et al. 1993).

The soil seedbank plays an important role in plant community conservation (Amiaud and Touzard 2004). Despite this importance, forest managers typically focus on the diversity-disturbance relationships of aboveground vegetation communities (Cheal 2010; Suganuma et al. 2014). It is theorised that soil seedbank diversity should increase and then decrease with time since disturbance (Amiaud and Touzard 2004). However, empirical research has found a continual increase (Milberg 1995), continual decrease (Pickett and McDonnell 1987; Roberts and Vankat 1991; Bakker et al. 1996; Omand et al. 2014) or no pattern (Ne'eman and Izhaki 1999; Wills and Read 2007) over time. These findings match those described for aboveground vegetation: a lack of a single unified pattern of change (Christensen 2014). Soil seedbank research has mostly occurred in longabandoned grasslands, Juniperus shrub lands or tropical forests. There is a relative paucity of research on soil seedbank dynamics in sclerophyllous forest ecosystems with dense shrub understories (Parker and Kelly 1989; Auld et al. 2000). Species with soil-stored seed dominate these ecosystems (Auld et al. 2000), suggesting this seedbank will be important for their post-fire persistence (Keeley 1991; Pausas et al. 2004).

Within the Mediterranean sclerophyllous shrubby ecosystems of Australia, prescribed burning is occurring across a diverse range of environmental conditions. This burning is predominantly a fuel reduction treatment aimed at wildfire risk reduction to human life and assets; however, it is also increasingly being used for the protection and promotion of ecological values (Penman et al. 2011). In south-west Australia, prescribed fire is used to manage fire regimes and conserve biodiversity through the maintenance of spatial and temporal patterns of growth stages (Burrows and McCaw 2013). In south-east Australia, the growth stage classification model has formed the basis of prescribed burning practices for wildfire management (Cheal 2010). Land managers in Victoria, south-east Australia, are attempting to apply a suite of prescribed burning regimes to create a mix of growth stages across a landscape as a means of conserving biodiversity (Di Stefano et al. 2013). However, spatial variability in plant-diversity-disturbance dynamics are not well understood in shrub dense forest ecosystems, such as heathy-woodland, where this burning generally occurs (Cheal 2010). Soil seedbank diversity can be influenced by spatial variability (e.g. geographic location) (Ne'eman and Izhaki 1999), environmental variability (e.g. soils) (Warr et al. 1993) and temporal (e.g. time since fire, TSF) (Zammit and Zedler 1988) heterogeneity. Understanding the relative influence of each of these factors will assist managers in conserving biodiversity through prescribed burning.

In this study, we examined the species richness and composition of a soil seedbank with increasing TSF, environmental variability and spatial variability in a fire-prone heathy-woodland in the Greater Otway National Park of south-east Australia. A combination of wildfire and prescribed burning has created a range of TSF, which have been categorised into growth stages from juvenile to old (Department of Primary Industries 2013).
To disentangle the independent effects of TSF, environment and space at a landscape scale, we examined the soil seedbank in heathy-woodland within three discrete regions within the Park. We had two primary aims. First, we examined species richness of the seedbank with TSF in each region to test for discernible patterns. Second, we examined the drivers of seedbank composition by exploring the role of fire, environmental factors and spatial variability separately and in interaction. We predicted that, as with the aboveground flora (Cohn et al. 2015), environmental and spatial variability would influence seedbank diversity more than would TSF. This research will inform managers about soil seedbank dynamics within the 'successional stages' used to manage plant diversity and test the appropriateness of current management practices in this region.

\section{Materials and methods}

\section{Study area}

The study area is located within the heathy-woodlands of the Otway Ranges region, $130 \mathrm{~km}$ west of Melbourne in south-east Australia (Fig. 1). The climate is Mediterranean type (Dodson 2001), with warm summers, mild winters and winter-dominant rainfall. The vegetation is dry sclerophyll, characterised by a low Eucalyptus baxteri (Benth.) Maiden \& Blakely ex J.M. Black (Brown Stringybark)-dominated overstorey and diverse heathy understorey. This community has been described as heathy-woodland in the Ecological Vegetation Class (EVC) classification system used in Victoria (Department of Sustainability and Environment 2012). Three discrete heathy-woodland regions exist around the townships of Anglesea, Forrest and Carlisle River (Fig. 1a). Although classified as the same EVC, land managers have described two slightly different forms of heathy-woodland within the three regions. The first is common and widespread around Forrest and Carlisle River, and the second around Anglesea. Common understorey species used to classify the two forms are listed in Table S1 in the Supplementary material, available online only. Wildfire last burnt the Anglesea region in 1983 and the Forrest and Carlisle River regions in 1939. Since 1983, all regions have been the subject of prescribed burning, resulting in a highly heterogeneous fire history within the heathy-woodland, making it particularity suited to research regarding plant seedbank richness and composition in response to TSF. The three regions also differ in annual average rainfall and temperature (Table 1), allowing investigation of potential interactions between post-disturbance diversity processes, environmental variation and regional productivity.

Using fire history layers from geographic information system (GIS) datasets, the landscape was stratified into categories that represent growth and development stages in post-fire heathywoodland (Cheal 2010): 0-3 (juvenile); 4-10 (young); 11-30 (mature); and $>30$ (old) years since fire. Local forest managers refer to these as 'growth stages'; however, in the context of this research they will be called 'successional stages'. Fig. 2 illustrates the vegetation structure and biomass consistent within the four stages. Using a chronosequence approach we established 71 sites, representative of the four successional stages, across the three regions (Table 1). The chronosequence method is a space-for-time sampling tool for studying the temporal dynamics of plant communities across multiple timescales (Walker 

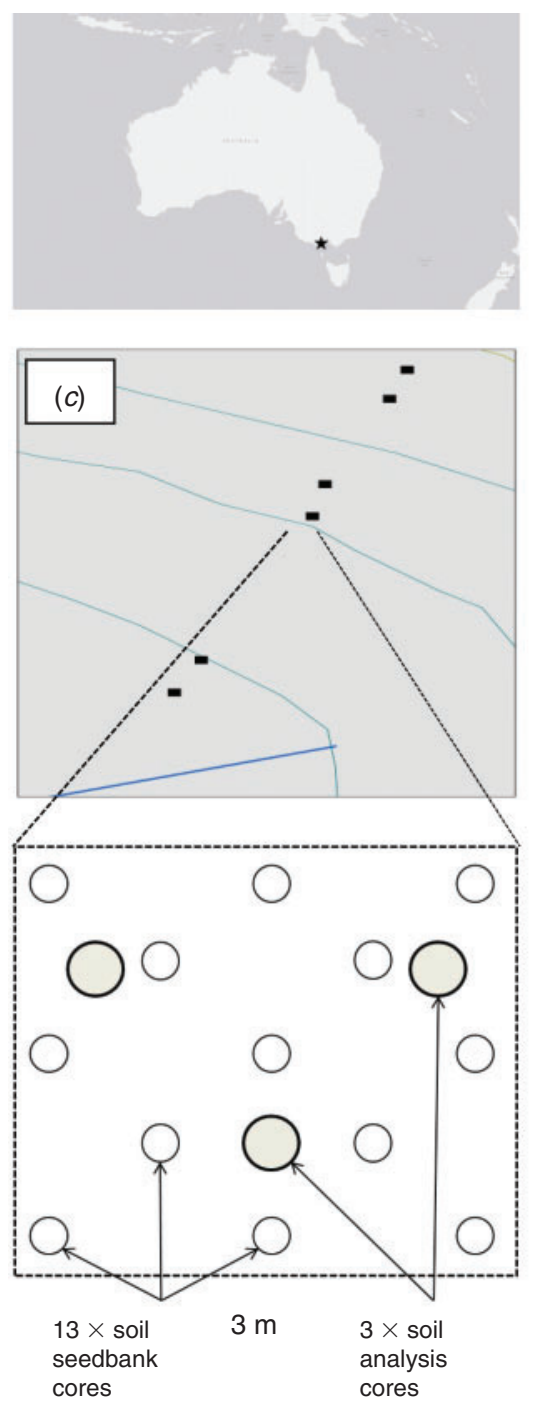
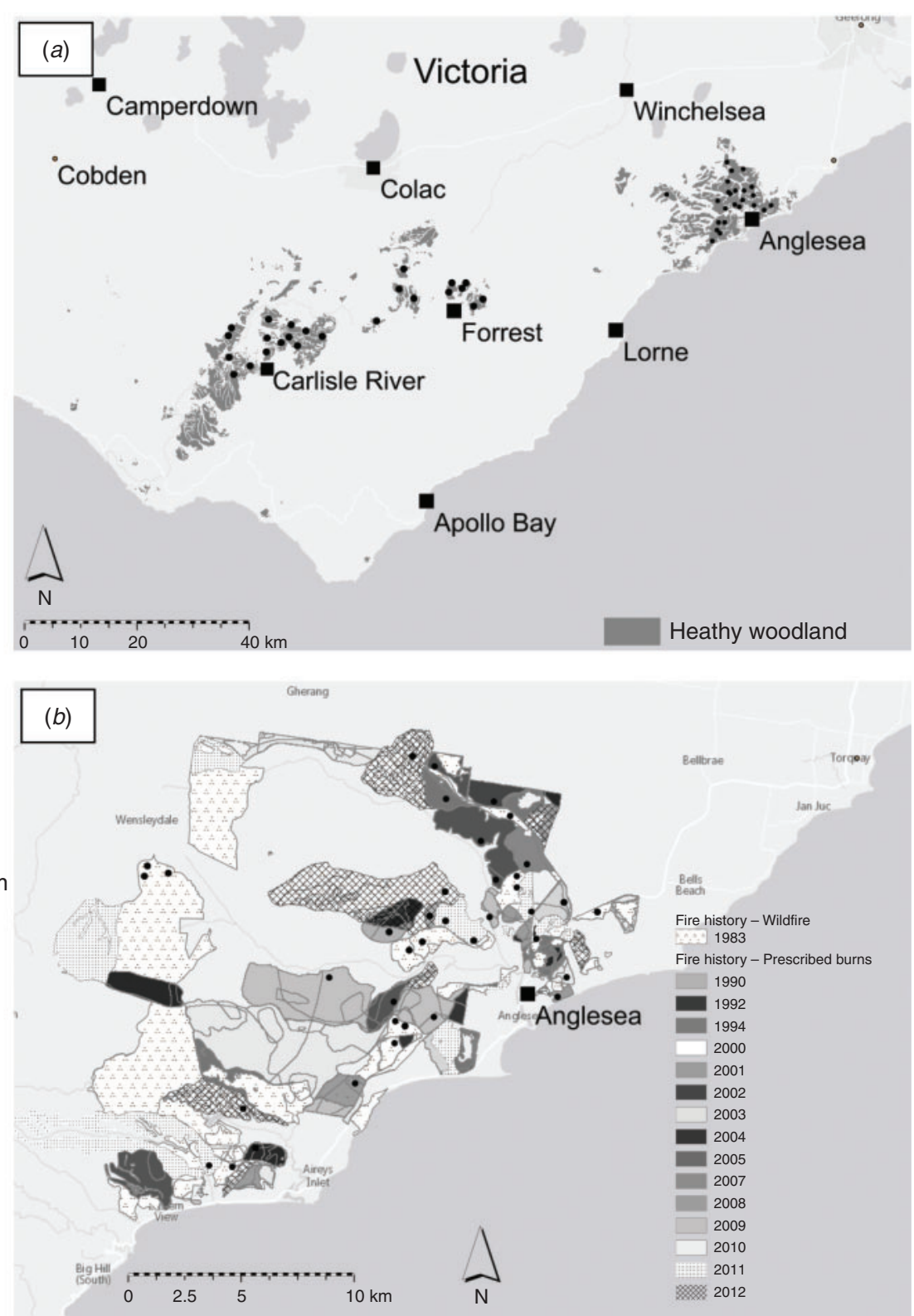

Fig. 1. Study area in the Otway Ranges. (a) Sites, indicated by black dots, within the three heathy-woodland regions (Anglesea, Forrest and Carlisle River) in south-eastern Australia. (b) Fire history and sites (black dots) within the Anglesea region. (c) Layout of six quadrats per site running from ridge to gully (black dashed line indicates transect, undashed blue line indicates creek). There were 13 soil seedbank cores and three soil analysis cores within each quadrat.

et al. 2010). An assumption of using TSF as a temporal scale is that the resulting community dynamic is a consequence of the last fire, and not the entire fire history or last fire type (prescribed or wildfire). Chronosequences are suitable for measuring plant diversity and soil characteristic changes at decadal to millennial timescales. Therefore, at the timescale sampled here (1-75 years) this approach is appropriate (Walker et al. 2010). Further, this was a natural experiment, meaning an optimal sampling design with sites having identical fire histories is difficult to achieve. We have attempted to address the assumptions of this design through independent ageing of sites (see below) and including fire history parameters in the data analyses. Criteria for site selection included (1) heathy-woodland of a minimum size of 1 ha; (2) being burnt by separate fires allowing sample independence (Fig. 1b); and (3) replicating each successional stage (Table 1). Different wildfire histories between regions resulted in an unbalanced design with some small sample sizes, which was addressed by using TSF as a continuous variable in most analyses (indicated in the Methods), rather than successional stage as a categorical variable.

Heathy-woodlands have a high understorey biomass with an often-sparse overstorey. Fuel reduction fires often aim to reduce around $90 \%$ of this understorey biomass (Department of Primary Industries 2013), meaning prescribed fire is often more severe than 
in adjacent ecosystems and somewhat congruent with the effects of wildfire. For this reason, we assumed the most recent fire consumed all understorey biomass at our sites, and the next fire will do the same, resetting the system to the juvenile stage. This assumption is important, as the purpose of this research is to ascertain if burning at different TSF would result in different juvenile stage compositions from the soil seedbank, or if there is no difference; meaning juvenile compositions are independent of pre-fire successional stage. To validate the GIS mapping of TSF and the assumption of understorey consumption in the last fire at the site scale, we independently aged at least 30 individual Banksia marginata shrubs using growth whorls (Jenkins et al. 2005).

\section{Sampling and treatment}

Transects were established randomly within each site, extending from ridge to gully, to sample topographic variation. At each of

Table 1. Climate and landscape variables describing the three heathy-woodland regions

Rainfall and temperature as measured by the Bureau of Meteorology for Anglesea, Forrest and Carlisle River

\begin{tabular}{lccc}
\hline & Anglesea & Forrest & Carlisle River \\
\hline Size (ha) & 6187 & 1500 & 11509 \\
Rainfall (mm) & & & \\
$\quad$ Annual mean & 814 & 1041 & 1070 \\
$\quad$ Summer mean & 45 & 51 & 54 \\
$\quad$ Winter mean & 83 & 121 & 123 \\
Temperature $\left({ }^{\circ} \mathrm{C}\right)$ & & & \\
$\quad$ Annual mean maximum & 18.2 & 17.7 & 18.5 \\
Annual mean minimum & 10.6 & 6.9 & 6.8 \\
Summer mean & 18.1 & 16.8 & 17.1 \\
$\quad$ Winter mean & 10.8 & 7.9 & 8.4 \\
Altitude (m) & $40-200$ & $170-190$ & $130-230$ \\
Growth stage, sites sampled & & & 4 \\
Juvenile $(0-3$ years) & 3 & 2 & 2 \\
Young $(3-10$ years) & 8 & 7 & 7 \\
Mature $(11-30$ years) & 13 & 8 & 6 \\
Old $(>30$ years) & 5 & 6 & 19 \\
Total $(n)$ & 29 & 23 & \\
\hline
\end{tabular}

three positions (ridge, mid-slope and gully), two $3 \times 3-\mathrm{m}$ quadrats were sampled (Fig. 1c). Small soil cores (6-cm diameter, 5-cm depth) were extracted at 13 positions in each quadrat and bulked, resulting in three composite soil samples per transect (26 cores per topographic position). Cores sampled the top 5-cm soil layer where most seeds are found (Carroll and Ashton 1965) and surface litter was included (i.e. in the soil core) as a source of fresh seed (Enright and Kintrup 2001). The sampling intensity of soil per experimental unit of six quadrats (78 soil cores, $0.22 \mathrm{~m}^{-2}, 1.10 \mathrm{~m}^{3}, 0.41 \%$ ) was consistent with similar studies (Enright and Lamont 1989; Wills and Read 2007). Soil cores were collected in the two consecutive autumns (February-April of 2013 and 2014) to capture seeds released in spring and summer (Enright and Kintrup 2001).

For logistical reasons, composite soil seedbank samples were treated separately, and then the data pooled for the whole transect (the experimental unit) for subsequent analyses. Composite soil samples were air dried, sieved (4-mm diameter) to remove litter, rock and other non-soil substrate, and mixed thoroughly. Each composite sample was further divided into three sub-samples for treatment. Smoke and heat enhance the germination of many species within heathy-woodland (Enright and Kintrup 2001). Therefore, one sub-sample was treated with high heat and smoke, one low heat and smoke, and one no heat or smoke and kept at room temperature (control). High and low heat treatments occurred by heating samples in aluminium trays to a depth of $2 \mathrm{~cm}$ in ovens at $95^{\circ} \mathrm{C}$ for 60 and $6 \mathrm{~min}$, respectively. Temperatures were measured at $1-\mathrm{cm}$ depth in each sample using sensors (DS1922 L I-buttons; Maxim Integrated Products, www.maxim-ic.com). The high heat frequently reached $80^{\circ} \mathrm{C}$, known to maximise germination of hard-coated shrub seeds (Auld and O'Connell 1991), and the low heat frequently matched the $30-50^{\circ} \mathrm{C}$ found to promote sedge and grass species germination (Warcup 1980). We applied smoke to the heated soil samples after they had cooled. Smoke water production followed Enright and Kintrup (2001), using a combination of fresh and dry foliage from Eucalyptus baxteri and associated understorey shrub species. Pre-heated sub-samples were soaked with $400 \mathrm{~mL}$ of smoke water, mixed thoroughly, and allowed to sit. Heat and smoke were used in combination to maximise germination, rather than to compare results from treatments.

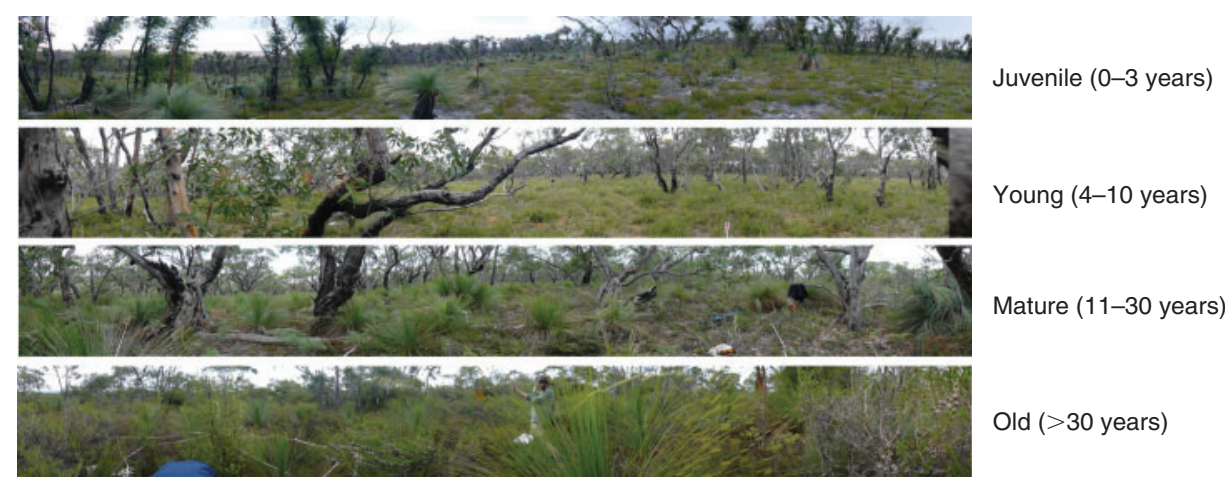

Fig. 2. Vegetation structure and biomass consistent within the four post-fire successional stages. The juvenile stage is characterised by complete understorey consumption. Understorey vegetation slowly increases with time until the shrub layer is again dominant in the mature and waning stages. 
Soil seedbank samples were spread to $2.5-\mathrm{cm}$ depth within plastic seedling trays and placed randomly in a climate-mediated $\left(\sim 16^{\circ} \mathrm{C}\right.$ at night and $26^{\circ} \mathrm{C}$ during the day) glasshouse with automatic irrigation. Due to limited glasshouse space, two trial periods ran from August 2013 to January 2014 and May 2014 to October 2014, each for 24 weeks. Tray positions were re-randomised throughout the trial to reduce position bias. Identifying, counting and removing of seedlings occurred periodically to reduce competition and increase germination. Identification occurred through reference to expert opinion and available literature (Walsh and Ross 2003; Mayfield 2013; Bull 2014). Once germinates ceased appearing, we turned the soils to promote germination of any remaining seeds within the soil profile.

We derived environmental variables from digital data layers and measurements in the field at the time of sampling (Table 2). Data layer variables included landscape parameters obtained from CSIRO soil and landscape grids (CSIRO 2015); site-scale climatic variables obtained from spatial interpolations of monthly data between 1950 and 2000 (WorldClim 2013); and site-scale fire variables generated from spatial datasets in ArcMap 10. In addition to those described above, we collected 18 soil samples (three within each quadrat) using bulk density rings (6.5-cm diameter, $5-\mathrm{cm}$ depth) (Fig. 1c) to measure site-scale soil bulk density, organic matter content, particle size, $\mathrm{pH}$ and electrical conductivity (Roberts 1986; Carter 1993) (Table 2).

\section{Statistical analyses}

\section{Aim 1: Species richness patterns with time since fire}

Regression analysis examined relationships between species richness of the seedbank (response variable) and TSF (predictor variable). We used TSF as a continuous variable here as we were interested in the functional form of richness patterns along a continuous scale. We fitted linear, quadratic and logarithmic models to the raw data for each region separately, and the raw data pooled across all the regions. To explore the effect of the spatially nested design at a landscape scale (raw data pooled across all regions), we used linear mixed models (LMMs), which rely on the response variable (in this case richness) having a normal (Gaussian) distribution (Quinn and Keough 2002). Count data, such as richness, would normally have a Poisson distribution (Bolker et al. 2009); however, data exploration indicated LMMs were appropriate. We used region as a random effect and TSF, site location (latitude and longitude), and average annual rainfall as fixed effects. We modelled the single, additive and multiplicative effects of each fixed variable.

Table 2. Environmental predictor variables collected either on site or through digital geographic information system layers DEPI, Department of Environment and Primary Industries

\begin{tabular}{|c|c|c|c|}
\hline Field measured predictors - soil & Unit & Method of measurement & Citation \\
\hline Clay content & $\%$ & Particle size analysis & Wilke 2005 \\
\hline Silt content & $\%$ & Particle size analysis & Wilke 2005 \\
\hline Bulk density & $\mathrm{g} \mathrm{cm}^{-3}$ & Oven dry weight & Wilke 2005 \\
\hline Organic matter content & $\%$ & Loss on ignition & Wilke 2005 \\
\hline Soil $\mathrm{pH}$ & - & $1: 5$ soil water solution & Wilke 2005 \\
\hline Soil electroconductivity & $\mathrm{dS} \mathrm{cm} \mathrm{cm}^{-1}$ & $1: 5$ soil water solution & Wilke 2005 \\
\hline Field measured predictors - landscape & Unit & Method of measurement & Citation \\
\hline Northness (cosine-transformed degrees) & $\circ$ & Compass & Roberts 1986 \\
\hline Westness (sine-transformed degrees) & $\circ$ & Compass & Roberts 1986 \\
\hline Slope & $\%$ & Clinometer, $3 \times$ long transect & - \\
\hline Basal area & $\mathrm{m}^{2} \mathrm{ha}^{-1}$ & Basal sweep, $3 \times$ long transect & - \\
\hline Time since fire & years & Counting Banksia whorls & Jenkins et al. 2005 \\
\hline Available water capacity & $\%$ & Soil water-holding capacity & http://www.clw.csiro.au/ \\
\hline Total nitrogen & $\%$ & Mass fraction of total nitrogen & http://www.clw.csiro.au/ \\
\hline Total phosphorus & $\%$ & Mass fraction of total phosphorus & http://www.clw.csiro.au/ \\
\hline Digital layer measured predictors - landscape & Unit & Description & Citation \\
\hline Rainfall & mm year $^{-1}$ & Average annual rainfall (1950-2000) & http://www.worldclim.org/bioclim \\
\hline Topographic wetness index & - & Relative wetness of site & http://www.clw.csiro.au/ \\
\hline Plan curvature & - & Rate of change of aspect (across slope) & http://www.clw.csiro.au/ \\
\hline Profile curvature & - & Rate of change of slope & http://www.clw.csiro.au/ \\
\hline Net radiation January (Summer) & - & Mean monthly solar radiation & http://www.clw.csiro.au/ \\
\hline Net radiation July (Winter) & - & Mean monthly solar radiation & http://www.clw.csiro.au/ \\
\hline Time since fire & years & Year of last fire & DEPI \\
\hline Fire frequency & count & Recorded fire count & http://www.clw.csiro.au/ \\
\hline Fire type & - & Last fire type (prescribed or wildfire) & http://www.clw.csiro.au/ \\
\hline
\end{tabular}


Mixed models were used because the random effect allows for nested data structures (as in this study) and spatial autocorrelation (in this case between sites (fixed) within the same region (random)). To compare the goodness of fit for all models we relied on restricted maximum likelihood estimation and Akaike's Information Criterion for small sample size (AICc) (Zuur et al. 2009; Mazerolle 2011). Model assumptions were validated by (1) plotting residuals $v s$ fitted values to verify homogeneity; (2) examining a histogram of the residuals for normality; and (3) plotting residuals vs each fixed explanatory variable to check independence (Zuur et al. 2009). Modelling, validation and model selection were undertaken in $\mathrm{R}$ using the packages 'Ime4' and 'AICcmodavg' ( $\mathrm{R}$ version 3.0.2, AICcmodavg version 1.32; Mazerolle 2011) and following the methods of Zuur et al. (2009).

Aim 2: Composition change with time since fire, environmental factors and spatial variability

Constrained ordination procedures explored site- and landscape-scale influences on seedbank composition. This technique allowed us to determine which set of environmental variables best explained seedbank composition (Ter Braak and Šmilauer 2012), and if they were acting independently of fire. We initially included TSF as a continuous predictor variable; however, its contribution was small so it was subsequently omitted from further modelling. We were also more interested in examining the temporal processes influencing composition with TSF, rather than time itself. To produce an independent subset, collinearity in environmental variables was reduced using principal components analysis and normality of the remaining checked (IBM SPSS Statistics ver. 20; IBM 2011). Abundance data were $\log (x+1)$ transformed to reduce the influence of abundant species. Initial de-trended canonical correspondence analysis results indicated short gradient lengths (i.e. linear relationships) and the use of redundancy analysis (RDA) was appropriate (Ter Braak and Šmilauer 2012).

To account for spatial structuring of seedbank composition variation, a matrix based on the latitude and longitude of each site was constructed containing the terms for a cubic trend surface polynomial $\left((\mathrm{X}+\mathrm{Y})+(\mathrm{X} \times \mathrm{Y})+\left(\mathrm{X}^{2}+\mathrm{Y}^{2}\right)+\right.$ $\left.\left(\mathrm{X}^{2} \times \mathrm{Y}\right)+\left(\mathrm{X} \times \mathrm{Y}^{2}\right)+\left(\mathrm{X}^{2} \times \mathrm{Y}^{2}\right)\right)($ Borcard et al. 1992). By using this method we were able to separate and partition the effects of spatial variability from the effects of environmental variability (Šmilauer and Lepš 2014). Partial-redundancy analysis (pRDA) then described the capacity of the measured environmental variation to explain seedbank composition after controlling for the effect of spatial variation. Forward selection determined the marginal and conditional effect of each environmental and spatial variable on composition during each ordination procedure (RDA, surface polynomial construction and pRDA) and built an environmental model that best explained total variation. Monte Carlo permutation (999 permutations) tested the statistical significance of the relationship between the species matrix and each environmental and spatial variable, with those significant $(P \leq 0.05)$ added to the model. Variance partitioning (Borcard et al. 1992) then enabled separation of the drivers of seedbank composition into the independent effect of (a) environmental variability; (b) spatial variability; and (c) the shared effect attributable to spatio-environmental co-variation.
Analyses were completed using CANOCO for Windows ver. 5.03 (Ter Braak and Śmilauer 2012). To facilitate interpretation of these composition models, we tested for relationships between the contributing environmental variables and TSF, latitude, and longitude (as continuous variables) using correlation analysis, and fire count (fire history), last fire type (fire history) and region (as categorical variables) through univariate ANOVA analysis (IBM SPSS Statistics ver. 20 (IBM 2011)).

To further explore patterns in composition with TSF, we calculated the relative abundance and absolute densities (seedlings $\mathrm{m}^{-2}$ ) of different functional groups (life form and fire persistence traits) within the successional stages. Life forms included shrub, herb, sedge and grass. Fire response traits included facultative $(\mathrm{R} / \mathrm{S})$, obligate seeding $(\mathrm{S})$ and re-sprouting (R). Here we used successional stage as a categorical variable.

\section{Results}

A total of 26923 seedlings germinated. We identified 92 species, with a further 6 taxa identified to genus level. This included 43 shrub and sub-shrub species (termed shrubs hereafter), 31 herbs, 11 sedge, 5 grass, 1 twiner and 1 tree species (Table S1). Of the seed-banking species listed in the aboveground EVC classification, $98 \%$ were present in the juvenile and young stage seedbanks, $92 \%$ in the mature and $75 \%$ in the old (Table S1). Epacris impressa was the most abundant species when considering seedlings $\mathrm{m}^{-2}$ of soil collected from the field (averages: Anglesea $45 \mathrm{~m}^{-2}$, Forrest $162 \mathrm{~m}^{-2}$, Carlisle River $41 \mathrm{~m}^{-2}$ ), accounting for $64 \%$ of all seedlings. Soil treatments promoted germination of sedge, grass and hard-coated shrub seeds. Banksia whorl counts were significantly correlated with GIS fire history mapping $(r=0.85, P<0.001)$, indicating this method was a useful validation tool. However, this correlation was stronger within the range of 2-20 years, after which the Banksia whorls underestimated the TSF reported on the fire mapping.

\section{Aim 1: Species richness patterns with time since fire}

Regression modelling suggested no consistent pattern in seedbank richness with TSF. Different models were significant $(P \leq 0.05)$ for each region and all had low explanatory power $\left(R^{2}\right.$ values, Table 3$)$. Model selection techniques indicated that for Anglesea a logarithmic model and for Carlisle River a linear model best fit the relationship, although other models, being within two AICc scores, had a similar degree of support. The quadratic model had the best fit for explaining the relationship in Forrest (Table 3, Fig. 3). Each model of best fit was significant but had consistently low explanatory power. The models did, however, describe a consistent initial increase in richness in the early years since fire, after which patterns differed throughout the later years (Fig. 3).

Across all regions, the pooled data suggested significant patterns in seedbank richness using all three models. AICc scores indicating the linear model best explained this pattern, although again its explanatory power was low (Table 3, Fig. 3). With the inclusion of covariates, LMMs suggested richness was best explained with the interactive fixed effects of TSF and site location, and the random effect of region (Table 4). This interaction indicates that TSF best explained richness across the landscape when the spatial nesting of sites within each 
Table 3. Relationships between species richness within the soil seed bank and time since fire

Lower Akaike's Information Criterion (AICc) scores indicate better model fit

\begin{tabular}{llrrrr}
\hline Region & Equation & \multicolumn{4}{c}{ Model summary } \\
& & $R^{2}$ & $F$ & $\begin{array}{c}\text { Significance } \\
(P)(\alpha=0.05)\end{array}$ & AICc \\
& & & & 0.080 & 189.9 \\
Anglesea & Linear & 0.06 & 3.2 & 0.012 & 186.5 \\
& Logarithmic & 0.12 & 6.8 & 0.029 & 187.9 \\
& Quadratic & 0.14 & 3.8 & 0.271 & 85.5 \\
Forrest & Linear & 0.06 & 1.3 & 0.059 & 82.8 \\
& Logarithmic & 0.17 & 4.0 & 0.006 & 78.0 \\
Carlisle River & Quadratic & 0.42 & 6.8 & 0.002 & 72.8 \\
& Linear & 0.44 & 13.4 & 0.005 & 74.6 \\
& Logarithmic & 0.39 & 10.7 & 0.006 & 74.8 \\
All regions & Quadratic & 0.48 & 7.3 & $<0.001$ & 337.6 \\
& Linear & 0.16 & 17.4 & $<0.001$ & 341.5 \\
& Logarithmic & 0.18 & 19.9 & $<0.01$ & 339.7 \\
& Quadratic & 0.16 & 8.8 & $<0.001$ & \\
\hline
\end{tabular}

region was accounted for. Average annual rainfall was highly correlated with site location $(r=-0.902)$, and therefore used as a covariate in a separate model. The inclusion of rainfall also improved model fit (Table 4).

Aim 2: Composition change with time since fire, environmental variability and spatial variability

Overall, environmental, spatial and spatio-environmental variability described $32.2 \%$ of the variation in seedbank composition. The initial RDA showed that spatial variability $\left(\mathrm{X}^{2}+\mathrm{Y}^{2}+\right.$ $\mathrm{X} \times \mathrm{Y}$ ) accounted for $16 \%$ of variation in seedbank composition (pseudo- $F=13.4, P=0.002$ ). Environmental variability initially described $20.4 \%$ of composition variation using a model with five environmental variables (bulk density, basal area, northness, clay content and silt content). When accounting for space (pRDA), this environmental model independently described $16.2 \%$ of the variation, indicating that $4.2 \%$ was attributed to shared co-variation (Table 5). Spatial variability independently described $11.4 \%$ of the variation. All five environmental variables had only a small spatial component in the variation they explained, ranging between 0.2 and $5.2 \%$ (Table 5). Variation in the environmental variables that influenced composition increased with age as successional stage groupings became less defined (Fig. 4). ANOVA results reported that basal area, northness and silt content did not differ significantly between fire variable categories, suggesting they were likely making independent contributions (Table 6). Bulk density differed significantly between regions (Table 6), suggesting it is part of the spatially structured environmental component (4.2\%). As expected, bulk density was negatively correlated with soil sand $(r=-0.395, P \leq 0.001)$ and organic matter $(r=-0.477, P \leq 0.004)$ content. Bulk density also varied significantly between successional stages, primarily due to a lower density observed in the juvenile stage. Clay content varied significantly between successional stages, due to the soil in the mature stage having a higher content. Both these results are evident in the pRDA ordination results (Fig. 4). Fire frequency

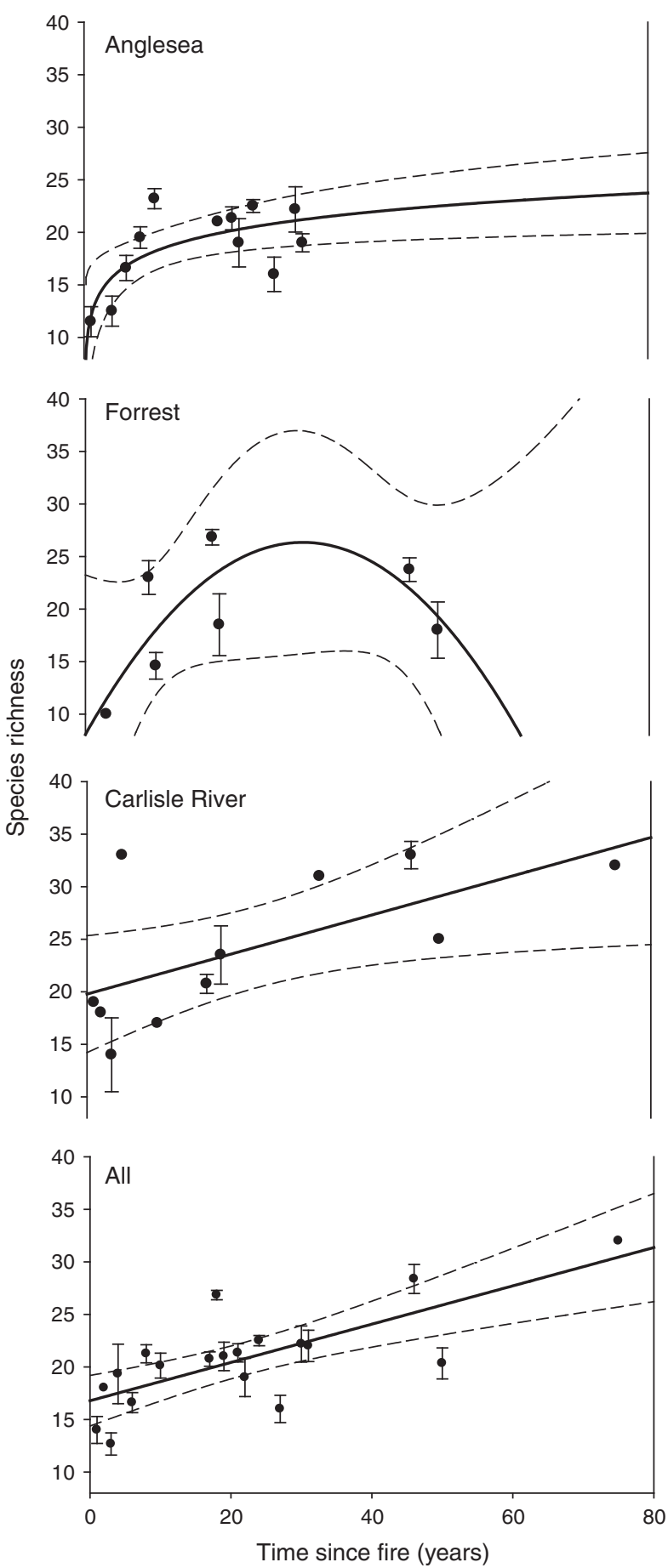

Fig. 3. Models of best fit for species richness relationships with time since fire. Anglesea, logarithmic; Forrest, quadratic; Carlisle River, linear; All, linear. Points are mean and standard error for richness from multiple sites with the same time since fire. Dotted lines are $95 \%$ confidence intervals for model predictions.

varied significantly with northness, suggesting that prescribed burns often occur more on north-facing slopes.

Relative and total abundances of each functional group contributing to the composition of the soil seedbank changed 
but did not follow a consistent pattern with TSF. All groups were represented in each successional stage (Fig. S1, showing only groups that changed). Facultative (R/S) shrubs contributed most to the overall composition in each successional stage and region, although the overwhelming abundance of Epacris impressa influenced these results. Between regions, we found the relative abundance of $(\mathrm{R} / \mathrm{S})$ shrubs, 34 species in total, higher at Forrest (driven by the single species Epacris impressa), (R) sedges higher at Anglesea, and (S) herbs higher at Anglesea and Carlisle River. The density (seedlings $\mathrm{m}^{-2}$ ) of $(\mathrm{R} / \mathrm{S})$ shrubs increased and then decreased with TSF in both Anglesea and Carlisle River. The density of (R) sedges decreased with TSF at Carlisle River.

\section{Discussion}

We found a weak positive relationship between soil seedbank richness and TSF; however, the nature of this relationship varied between regions. Results suggest that TSF in combination with spatially structured variability is most likely driving richness patterns. This indicates that regional variation, which could be environmental or climatic, is helping to drive richness patterns. Our results also suggest that environmental and spatial variability are attributing more to variation in seedbank composition than TSF.

Table 4. Models of richness with time since fire and added covariates Ordered from best to worst fit, $\Delta \mathrm{AICc}=$ change in Akaike's Information Criterion. $R^{2}=$ variance explained by the entire model. Response variable: species richness. All models with region as random factor

\begin{tabular}{|c|c|c|c|c|c|}
\hline Model & $\begin{array}{l}\text { Number of } \\
\text { parameters }\end{array}$ & $\mathrm{AICc}$ & $\Delta \mathrm{AICc}$ & $\mathrm{AICcWt}$ & $R^{2}$ \\
\hline $\mathrm{TSF} \times$ site location ${ }^{\mathrm{A}}$ & 7 & 490.17 & 0 & 0.74 & 0.38 \\
\hline $\mathrm{TSF}+$ site location $^{\mathrm{A}}$ & 6 & 492.79 & 2.61 & 0.20 & 0.33 \\
\hline $\begin{array}{l}\text { TSF + rainfall } \\
\text { (annual average) }\end{array}$ & 5 & 495.92 & 5.75 & 0.04 & 0.32 \\
\hline $\begin{array}{l}\mathrm{TSF} \times \text { rainfall } \\
\text { (annual average) }\end{array}$ & 6 & 497.95 & 7.78 & 0.02 & 0.31 \\
\hline TSF & 4 & 499.56 & 9.39 & 0.01 & 0.27 \\
\hline
\end{tabular}

${ }^{\mathrm{A}}$ latitude and longitude.
The overarching aim of this research was to ascertain if a discernible post-fire plant richness and composition pattern was evident in the seedbank of this heathy-woodland. Further, if a pattern did exist, this research aimed to explain the influence of TSF and/or spatial and environmental variability. Our results suggest no clear richness or composition pattern with TSF, indicating that propagules available for recruitment may stay constant with increasing time. Prescribed burning consumes most aboveground biomass in this ecosystem, indicating a return to the juvenile stage regardless of the pre-fire successional stage. Therefore, and most importantly, our results also suggest that seedbank compositions at both the juvenile and young stages

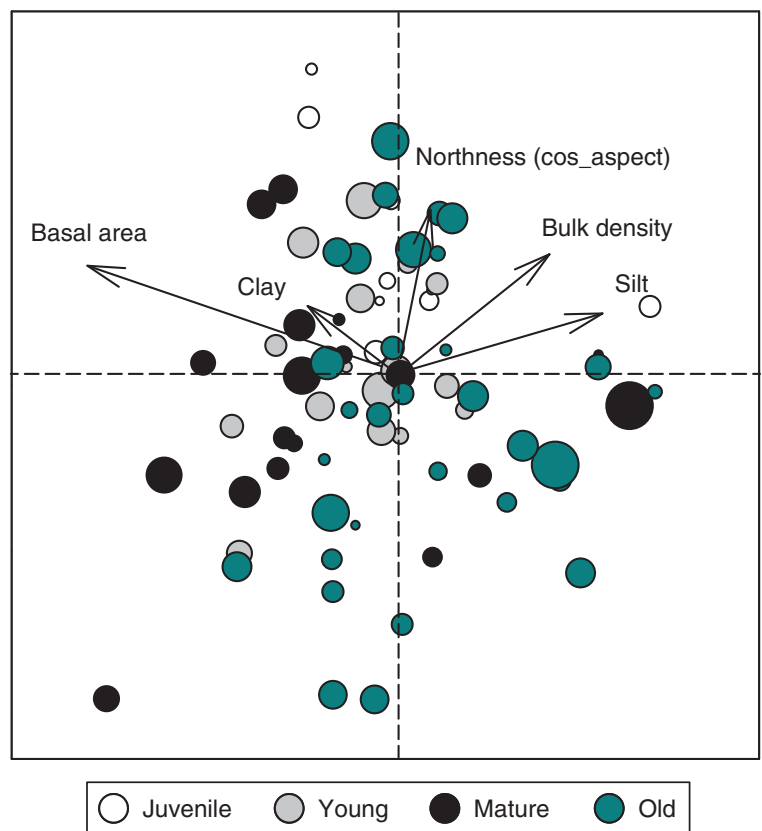

Fig. 4. Ordination results presenting relationships between site seedbank composition (successional stages) and the five modelled environmental variables (controlling for spatial effects). Bubble plot size relates to site richness. Shown are weak groupings of juvenile and young successional stages and increased variation in the environmental variables influencing composition with increasing age (older successional stage) as groups become less defined.

Table 5. Environmental predictors with significant relationships with the seedbank composition matrix

Variables used to model composition variation using redundancy analysis and partial-redundancy analysis

\begin{tabular}{|c|c|c|c|c|c|c|c|}
\hline \multirow[t]{2}{*}{ Environmental variable } & \multicolumn{3}{|c|}{ Constrained - without controlling for space } & \multicolumn{3}{|c|}{ Partial-constrained - controlling for space } & \multirow{2}{*}{$\begin{array}{c}\text { Contribution to } \\
\text { spatial structure } \\
\Delta \text { change in } \\
\text { variation } \\
\text { described }(\%)\end{array}$} \\
\hline & $\begin{array}{c}\text { Variation } \\
\text { described }(\%)\end{array}$ & Pseudo- $F$ & $\begin{array}{l}\text { Significance } \\
(P)(\alpha=0.05)\end{array}$ & $\begin{array}{c}\text { Variation } \\
\text { described (\%) }\end{array}$ & Pseudo- $F$ & $\begin{array}{l}\text { Significance } \\
(P)(\alpha=0.05)\end{array}$ & \\
\hline Bulk density $\left(\mathrm{g} \mathrm{cm}^{-3}\right)$ & 9.3 & 5.7 & 0.002 & 4.1 & 3.8 & 0.002 & 5.2 \\
\hline Basal area $\left(\mathrm{m}^{2} \mathrm{ha}^{-1}\right)$ & 4.2 & 3.5 & 0.002 & 5.1 & 3.1 & 0.002 & 0.9 \\
\hline Northness (cosine-degrees) & 2 & 1.6 & 0.040 & 2.2 & 1.7 & 0.018 & 0.2 \\
\hline Clay content $(\%)$ & 2 & 1.7 & 0.036 & 2.2 & 1.7 & 0.016 & 0.2 \\
\hline Silt content $(\%)$ & 2.9 & 2.4 & 0.002 & 2.6 & 1.6 & 0.021 & 0.3 \\
\hline Total & 20.4 & & & 16.2 & & & 6.8 \\
\hline
\end{tabular}


may not be significantly different from stands at older successional stages. These results also highlight that the propagules from all different functional types are likely to be available for recruitment soon after fire. Additionally, most species present in the juvenile and young age class seedbanks are included in the aboveground composition classification list used for growth stage management, indicating that a significant change in species composition post-fire is unlikely. Although no strong relationship between TSF and richness was evident, there was a consistent initial increase in richness early after fire within and across all regions. This indicates that repeated fires at short intervals could favour certain species and functional groups over others (Enright et al. 2015).

Our findings suggest that the soil seedbank richness of this ecosystem does not follow a predictable pattern with increasing TSF. Although significant patterns existed both within and across all regions, relationships were weak and had low explanatory power. Further, there were multiple functional models of best fit in two regions, suggesting that overall the response of seedbanks in heathy-woodland systems of south-east Australia are inconsistent. Given the importance of regionally specific aboveground vegetation patterns, this response is not surprising and suggests that a unified theory on plant richness with succession may not be achievable. However, significant linear relationships were highlighted, contradicting other research undertaken in the same ecosystem (Wills and Read 2007) that found no significant relationships, and other ecosystems finding higher richness at early successional stages, which then declined with time (Livingston and Allessio 1968; Pickett and McDonnell 1987; Roberts and Vankat 1991; Amiaud and Touzard 2004).

We conclude that environmental and spatial variability influenced species composition more than did TSF, which is supported by the findings of Ne'eman and Izhaki (1999). At a landscape scale, soil bulk density explained the largest amount of variation in seedbank composition, suggesting that it may be the largest driver of variation between regions. Bulk density is influenced by a soil's organic matter content and affects soil water-holding capacity. Lower bulk density often indicates higher organic matter content, as in this case, and greater porosity (Gupta and Larson 1979), which can lead to higher productivity (Field et al. 2009). Higher porosity could also affect the ability of seeds to move into the soil through rain percolation and persist in the seedbank (Warr et al. 1993). Later successional stage seedbanks still dominated by seed from early successional species have been attributed to this movement (Warr et al. 1993; Silvertown and Charlesworth 2009). The bulk density of soils can also influence the non-dormant portion of the seed of many species in the inter-fire period. Changes in bulk density can influence soil moisture content, which can stimulate non-dormant seed germination but also speed up the degradation of dormant seed (Moreno-Casasola et al. 1994).

Our results also suggest that the relative abundance of functional trait groups stays reasonably uniform with TSF (Fig. S1). This suggests that a diversity of plant functional traits is present from the initial post-fire period through to later successional stages. Facultative (R/S) shrubs contributed most to the overall composition in each successional stage in each region. This conflicts with the findings of Roberts and Vankat (1991), who found shrubs absent in early, but present in late succession. Dominance of a single species in the seedbank aligns with the findings of past research within heathlands in general (Granstrom 1988; Zammit and Zedler 1988; Mitchell et al. 1998). The lack of seed from obligate seeding shrubs (in this case larger seeds) could be attributed to herbivores (Vander Wall et al. 2006), ant movement to localised positions (Beaumont et al. 2011) or the lack of obligate seeding species in the observed aboveground vegetation (Table S1).

If the management goal is to maintain species diversity broadly across this ecosystem, then our results indicate it is unlikely that prescribed burning will cause significant changes in aboveground species richness or composition post-fire. However, both the richness and composition data did include a spatially structured component, suggesting that specialised species exist only within a single region or successional stage. For example, Pultenaeae laxiflora (S shrub) (only in old Anglesea) and Hibbertia acicularis (R/S shrub) (only in young, mature and old Carlisle River) are specialist species, with abundant seeds in only one or a few successional stages in a single region. Aotus ericoides $(\mathrm{R} / \mathrm{S}$ shrub) only occurred in high abundance in the mature stage in Carlisle River and the old stage in Forrest. Epacris impressa (R/S shrub) and Isolepis inundata (S herb) are generalist species, with abundant seeds in all successional stages and regions (Table S1). Further, the overlap between the species found in the soil seedbank and those listed in the EVC for aboveground management decreased with TSF, indicating that some species prominent in management decisions considering aboveground species diversity may be disappearing from the

Table 6. Environmental variables contributing to composition models and their relationships with landscape-scale categorical and continuous variables

TSF, time since fire

\begin{tabular}{|c|c|c|c|c|c|c|c|}
\hline \multirow[t]{2}{*}{ Environmental variable } & \multicolumn{4}{|c|}{ Significance $(P)(\alpha=0.05)$} & \multicolumn{3}{|c|}{ Correlation $\left(R^{2}\right)$} \\
\hline & $\begin{array}{l}\text { Successional } \\
\text { stage }\end{array}$ & $\begin{array}{c}\text { Fire } \\
\text { frequency }\end{array}$ & $\begin{array}{c}\text { Fire type } \\
\text { (prescribed/wildfire) }\end{array}$ & Region & TSF & Longitude & Latitude \\
\hline Bulk density $\left(\mathrm{g} \mathrm{cm}^{-3}\right)$ & 0.017 & 0.126 & 0.050 & 0.001 & $<0.01$ & 0.30 & 0.27 \\
\hline Basal area $\left(\mathrm{m}^{2} \mathrm{ha}^{-1}\right)$ & 0.160 & 0.958 & 0.016 & 0.322 & 0.01 & $<0.01$ & $<0.01$ \\
\hline Northness (cosine-degrees) & 0.245 & 0.002 & 0.171 & 0.947 & 0.02 & $<0.01$ & $<0.01$ \\
\hline Clay content $(\%)$ & 0.001 & 0.074 & 0.516 & 0.970 & 0.07 & 0.01 & $<0.01$ \\
\hline Silt content $(\%)$ & 0.227 & 0.361 & 0.005 & 0.802 & 0.08 & $<0.01$ & $<0.01$ \\
\hline
\end{tabular}


seedbank with time. Therefore, if the management goal is to maximise diversity through prescribed burning, management practices should consider the variability in species richness and composition associated with TSF combined with environmental and spatial variability. The current mosaic burning approach (Cheal 2010), combined with consideration of region-specific environmental processes, may therefore be the most appropriate prescribed burning regime to apply in heathy-woodland communities in south-east Australia.

Research in Mediterranean plant communities suggests that aboveground vegetation may be an important driver of soil seedbank composition (Ne'eman and Izhaki 1999; Rodrigo et al. 2012). It is likely that the composition of aboveground species is contributing to the unexplained variation in the seedbank researched here. Although such data would contribute to improved models, here we focussed on obtaining a better understanding of the soil seedbank, as this is where the knowledge is lacking in management paradigms. When considering other aspects of the fire regime the influence of aboveground species compositions may be greater. Frequent fire at a site with a high abundance of obligate seeding species aboveground could result in a decline of these species in the soil seedbank. The soil-stored seed of these species could be diminished if inter-fire intervals are too short for seedbank replenishment (Orscheg and Enright 2011; Enright et al. 2015). The seasonality of the fire could also affect the seedbank response if many of the aboveground species were obligate seeding with physiological dormancy, as they are known to delay germination until post-fire seasonal conditions are advantageous (Ooi et al. 2004; Tuckett et al. 2010). Fire severity could affect the seedbank response if many of the aboveground species are obligate seeding and serotinous (Cowling et al. 1987) or have hard-coated physically dormant seed (Auld and O'Connell 1991). However, in this soil seedbank study, our findings suggest a low abundance of obligate seeding species and a high abundance of facultative species. The fact that this is mimicked in the aboveground composition (see Table S1 for both aboveground and seedbank) suggests that, at the community level, heathy-woodland ecosystems may be resilient to a wide range of fire regimes (prescribed, wildfire or in interaction).

\section{Conclusions}

Prescribed burning as a management practice is increasing worldwide in fire-prone ecosystems such as heathy-woodlands. Therefore, it is of critical importance to consider the role of seedbanks in the response of the community to these changing fire regimes. Given the importance of seedbanks to the conservation of plant communities, increasing our understanding of plant-soil dynamics is important for developing holistic and robust management regimes. These regimes may need to be regionally specific if we are to prevent homogenising plant diversity and promote the conservation of biodiversity across the distribution of fire-prone woodlands in south-east Australia and beyond.

\section{Acknowledgements}

We are very grateful to Sabine Kasel and Tom Duff for assistance during the experimental design process. We are also grateful to Ben Smith and Julio Najera for field assistance. We are also grateful to Joe Greet and John
Del-Prat for species identification assistance. This research was funded by the Collaborative Research Network, to whom we are grateful. We would also like to thank the Department of Environment, Land, Water and Planning for their field assistance and funding.

\section{References}

Amiaud B, Touzard B (2004) The relationships between soil seed bank, aboveground vegetation and disturbances in old embanked marshlands of Western France. Flora - Morphology, Distribution. Functional Ecology of Plants 199, 25-35. doi:10.1078/0367-2530-00129

Andison DW, Marshall PL (1999) Simulating the impact of landscape-level biodiversity guidelines: a case study. Forestry Chronicle 75, 655-665. doi:10.5558/TFC75655-4

Auld TD, O’Connell MA (1991) Predicted patterns of postfire germination in 35 eastern Australian Fabaceae. Austral Ecology 16, 53-70. doi:10.1111/J.1442-9993.1991.TB01481.X

Auld TD, Keith DA, Bradstock RA (2000) Patterns in longevity of soil seedbanks in fire-prone communities of south-eastern Australia. Australian Journal of Botany 48, 539-548. doi:10.1071/BT99046

Bakker JP, Bakker ES, Rosen E, Verweij GL, Bekker RM (1996) Soil seed bank composition along a gradient from dry alvar grassland to Juniperus shrubland. Journal of Vegetation Science 7, 165-176. doi:10.2307/ 3236316

Beaumont KP, Mackay DA, Whalen MA (2011) Interactions between ants and seeds of two myrmecochorous plant species in recently burnt and long-unburnt forest sites. Austral Ecology 36, 767-778. doi:10.1111/ J.1442-9993.2010.02215.X

Bellingham PJ, Sparrow AD (2000) Resprouting as a life history strategy in woody plant communities. Oikos 89, 409-416. doi:10.1034/J.16000706.2000.890224.X

Benkobi L, Uresk DW (Eds) (1996) Seral stage classification and monitoring model for big Sagebrush/Western Wheatgrass/Blue grama habitat. In 'Proceedings, Shrubland Ecosystem Dynamics in a Changing Environment', 23-25 May 1995, Las Cruces, NM. (Ed. JR Barrow) USDA Forest Service, Intermountain Research Station, General Technical Report Int 338, pp. 69-73. (Ogden, UT)

Bolker BM, Brooks ME, Clark CJ, Geange SW, Poulsen JR, Stevens MHH, White J-SS (2009) Generalized linear mixed models: a practical guide for ecology and evolution. Trends in Ecology \& Evolution 24, 127-135. doi:10.1016/J.TREE.2008.10.008

Borcard D, Legendre P, Drapeau P (1992) Partialling out the spatial component of ecological variation. Ecology 73, 1045-1055. doi: $10.2307 / 1940179$

Bull M (Ed.) (2014) 'Flora of Melbourne: a Guide to the Indigenous Plants of the Greater Melbourne Area.' (Hyland House Publishing: Melbourne)

Burrows N, McCaw L (2013) Prescribed burning in southwestern Australian forests. Frontiers in Ecology and the Environment 11, e25-e34. doi:10.1890/120356

Carroll EJ, Ashton DH (1965) Seed storage in soils of several Victorian plant communities. Victorian Naturalist 82, 102-110.

Carter MR (Ed.) (1993) 'Soil Sampling and Methods of Analysis.' (Lewis Publishers: Boca Raton)

Cheal D (Ed.) (2010) 'Growth Stages and Tolerable Fire Intervals for Victoria's Native Vegetation Data Sets.' (Victorian Government: Melbourne)

Christensen N (2014) An historical perspective on forest succession and its relevance to ecosystem restoration and conservation practice in North America. Forest Ecology and Management 330, 312-322. doi:10.1016/ J.FORECO.2014.07.026

Cohn JS, Di Stefano J, Christie F, Cheers G, York A (2015) How do heterogeneity in vegetation types and post-fire age-classes contribute to plant diversity at the landscape scale? Forest Ecology and Management 346, 22-30. doi:10.1016/J.FORECO.2015.02.023

Connell JH (1978) Diversity in tropical rain forests and coral reefs. Science 199, 1302-1310. doi:10.1126/SCIENCE.199.4335.1302 
Cowling RM, Byron BL, Pierce SM (1987) Seed bank dynamics of four co-occurring Banksia species. Journal of Ecology 75, 289-302. doi: $10.2307 / 2260419$

CSIRO (2015) Soil and landscape grid of Australia. Available at http://www. clw.csiro.au/aclep/soilandlandscapegrid [Verified 10 August 2015]

Department of Primary Industries (2013) Fire operations plan 2013/ 14-2015/16 - Barwon South West Region. (Department of Primary Industries: Melbourne)

Department of Sustainability and Environment (2012) Ecological Vegetation Class (EVC) benchmarks for each bioregion. (Department of Sustainability and Environment: Melbourne)

Di Stefano J, McCarthy M, York A, Duff T, Slingo J, Christie F (2013) Defining vegetation age class distributions for multispecies conservation in fire-prone landscapes. Biological Conservation 166, 111-117. doi:10.1016/J.BIOCON.2013.06.022

Dodson JR (2001) Holocene vegetation change in the Mediterranean-type climate regions of Australia. The Holocene 11, 673-680. doi:10.1191/ 09596830195690

Enright NJ, Kintrup A (2001) Effects of smoke, heat and charred wood on the germination of dormant soil-stored seeds from a Eucalyptus baxteri heathy-woodland in Victoria, SE Australia. Austral Ecology 26, 132-141. doi:10.1046/J.1442-9993.2001.01096.X

Enright NJ, Lamont BB (1989) Seed banks, fire season, safe sites and seedling recruitment in five co-occurring Banksia species. Journal of Ecology 77, 1111-1122. doi:10.2307/2260826

Enright NJ, Fontaine JB, Bowman DMJS, Bradstock RA, Williams RJ (2015) Interval squeeze: altered fire regimes and demographic responses interact to threaten woody species persistence as climate changes. Frontiers in Ecology and the Environment 13, 265-272. doi:10.1890/ 140231

Field R, Hawkins BA, Cornell HV, Currie DJ, Diniz-Filho JAF, Guégan J-F, Kaufman DM, Kerr JT, Mittelbach GG, Oberdorff T, O’Brien EM Turner JRG (2009) Spatial species-richness gradients across scales: a meta-analysis. Journal of Biogeography 36, 132-147. doi:10.1111/ J.1365-2699.2008.01963.X

Fox JW (2013) The intermediate disturbance hypothesis should be abandoned. Trends in Ecology \& Evolution 28, 86-92. doi:10.1016/J.TREE. 2012.08.014

Garwood NC (1989) Tropical soil seed banks: a review. In 'Ecology of Soil Seed Banks'. (Ed. R Simpson) pp. 149-210. (Academic Press: San Diego)

Granstrom A (1988) Seed banks at 6 open and afforested Heathland sites in southern Sweden. Journal of Applied Ecology 25, 297-306. doi:10.2307/ 2403627

Gupta S, Larson W (1979) Estimating soil water retention characteristics from particle size distribution, organic matter percent, and bulk density. Water Resources Research 15, 1633-1635. doi:10.1029/ WR015I006P01633

Hall AR, Miller AD, Leggett HC, Roxburgh SH, Buckling A, Shea K (2012) Diversity-disturbance relationships: frequency and intensity interact. Biology Letters 8, 768-771. doi:10.1098/RSBL.2012.0282

IBM (2011) 'IBM SPSS Statistics for Windows, Version 20.0.' (IBM Corp: New York)

Jenkins ME, Morrison DA, Auld TD (2005) Use of growth characteristics for predicting plant age of three obligate-seeder Proteaceae species. Australian Journal of Botany 53, 101-108. doi:10.1071/BT04067

Keeley JE (1991) Seed germination and life history syndromes in the California chaparral. Botanical Review 57, 81-116. doi:10.1007/ BF02858766

Keeley JE (2009) Fire intensity, fire severity and burn severity: a brief review and suggested usage. International Journal of Wildland Fire 18, 116-126. doi:10.1071/WF07049

Kimmins JP (Eds) (2004) 'Forest Ecology: a Foundation for Sustainable Forest Management and Environmental Ethics in Forestry.' (PrenticeHall: New Jersey)
Korovin CN, Korzukhin MD, Butusov OB, Golovanov AS (2011) Longterm prediction of the dynamics of age-class and species composition of forests. Contemporary Problems of Ecology 4, 784-795. doi:10.1134/ S1995425511070101

Levin SA, Paine RT (1974) Disturbance, patch formation, and community structure. Proceedings of the National Academy of Sciences of the United States of America 71, 2744-2747. doi:10.1073/PNAS.71.7.2744

Livingston RB, Allessio ML (1968) Buried viable seed in successional field and forest stands, Harvard Forest, Massachusetts. Bulletin of the Torrey Botanical Club 95, 58-69. doi:10.2307/2483807

Mayfield E (Eds) (2013) 'Flora of the Otway Plain and Ranges. 2: Daisies, Heaths, Peas, Saltbushes, Sundews, Wattles and other Shrubby and Herbaceous Dicotyledons.' (CSIRO Publishing: Melbourne)

Mazerolle M (2011) AICcmodavg: model selection and multimodel inference based on (Q) AIC (c). R package version 1, 16.

Milberg P (1995) Soil seed bank after eighteen years of succession from grassland to forest. Oikos 72, 3-13. doi:10.2307/3546031

Mitchell RJ, Marrs RH, Auld MHD (1998) A comparative study of the seedbanks of heathland and successional habitats in Dorset, Southern England. Journal of Ecology 86, 588-596. doi:10.1046/J.1365-2745. 1998.00281.X

Moreno-Casasola P, Grime JP, Martínez ML (1994) A comparative study of the effects of fluctuations in temperature and moisture supply on hard coat dormancy in seeds of coastal tropical legumes in Mexico. Journal of Tropical Ecology 10, 67-86. doi:10.1017/S0266467400007720

Ne'eman G, Izhaki I (1999) The effect of stand age and microhabitat on soil seed banks in Mediterranean Aleppo pine forests after fire. Plant Ecology 144, 115-125. doi:10.1023/A:1009806507403

Noble IR, Slatyer RO (1980) The use of vital attributes to predict successional changes in plant communities subject to recurrent disturbances. Vegetatio 43, 5-21. doi:10.1007/BF00121013

Omand KA, Karberg JM, Beattie KC, O’Dell DI, Freeman RS (2014) Soil seed bank in Nantucket's early successional communities: implications for management. Natural Areas Journal 34, 188-199. doi:10.3375/043. 034.0208

Ooi M, Auld T, Whelan R (2004) Delayed post-fire seedling emergence linked to season: a case study with Leucopogon species (Epacridaceae) Plant Ecology 174, 183-196. doi:10.1023/B:VEGE.0000046171.97671. E6

Orscheg CK, Enright NJ (2011) Patterns of seed longevity and dormancy in obligate seeding legumes of box-ironbark forests, south-eastern Australia. Austral Ecology 36, 185-194. doi:10.1111/J.1442-9993. 2010.02135.X

Parker VT, Kelly VR (Eds) (1989) 'Seed banks in California chaparral and other Mediterranean climate shrublands.' (Academic Press: San Jose, CA)

Pausas JG, Bradstock RA, Keith DA, Jon EK (2004) Plant functional traits in relation to fire in crown-fire ecosystems. Ecology 85, 1085-1100. doi:10.1890/02-4094

Penman TD, Christie FJ, Andersen AN, Bradstock RA, Cary GJ (2011) Prescribed burning: how can it work to conserve the things we value? International Journal of Wildland Fire 20, 721-733. doi:10.1071/ WF09131

Pickett STA, McDonnell MJ (1987) Seed bank dynamics in temperate deciduous forest. American Journal of Botany 74, 637-638.

Quinn GP, Keough MJ (Eds) (2002) 'Experimental Design and Data Analysis for Biologists.' (Cambridge University Press: New York, NY)

Randall Hughes A, Byrnes JE, Kimbro DL, Stachowicz JJ (2007) Reciprocal relationships and potential feedbacks between biodiversity and disturbance. Ecology Letters 10, 849-864. doi:10.1111/J.1461-0248.2007. 01075.X

Richards SA, Possingham HP, Tizard J (1999) Optimal fire management for maintaining community diversity. Ecological Applications 9, 880-892. doi:10.1890/1051-0761(1999)009[0880:OFMFMC]2.0.CO;2 
Roberts DW (1986) Ordination on the basis of fuzzy set theory. Vegetatio 66, 123-131. doi:10.1007/BF00039905

Roberts T, Vankat J (1991) Floristics of a chronosequence corresponding to old field-deciduous forest succession in southwestern Ohio. II. Seed banks. Bulletin of the Torrey Botanical Club 118, 377-384. doi:10.2307/ 2997089

Rodrigo A, Arnan X, Retana J (2012) Relevance of soil seed bank and seed rain to immediate seed supply after a large wildfire. International Journal of Wildland Fire 21, 449-458. doi:10.1071/WF11058

Silvertown J, Charlesworth D (Eds) (2009) 'Introduction to Plant Population Biology.' (John Wiley \& Sons: New York, NY)

Šmilauer P, Lepš J (Eds) (2014) 'Multivariate Analysis of Ecological Data using CANOCO 5.' (Cambridge University Press: New York, NY)

Suganuma MS, de Assis GB, Durigan G (2014) Changes in plant species composition and functional traits along the successional trajectory of a restored patch of Atlantic Forest. Community Ecology 15, 27-36. doi:10.1556/COMEC.15.2014.1.3

Ter Braak C, Šmilauer P (Eds) (2012) 'Canoco Reference Manual and User's Guide: Software for Ordination (Version 5.0).' (Microcomputer Power: New York, NY)

Thompson K, Ooi MKJ (2010) To germinate or not to germinate: more than just a question of dormancy. Seed Science Research 20, 209-211. doi:10.1017/S0960258510000267

Tuckett RE, Merritt DJ, Hay FR, Hopper SD, Dixon KW (2010) Dormancy, germination and seed bank storage: a study in support of ex situ conservation of macrophytes of southwest Australian temporary pools. Freshwater Biology 55, 1118-1129. doi:10.1111/J.1365-2427.2010. 02386.X

Vander Wall SB, Esque T, Haines D, Garnett M, Waitman BA (2006) Joshua tree (Yucca brevifolia) seeds are dispersed by seed-caching rodents. Ecoscience 13, 539-543. doi:10.2980/1195-6860(2006)13 [539:JTYBSA]2.0.CO;2

Walker LR, Wardle DA, Bardgett RD, Clarkson BD (2010) The use of chronosequences in studies of ecological succession and soil development. Journal of Ecology 98, 725-736. doi:10.1111/J.1365-2745.2010. 01664.X

Walsh N, Ross JH (Eds) (2003) 'A Census of the Vascular Plants of Victoria.' (National Herbarium of Victoria: Melbourne)

Warcup JH (1980) Effect of heat-treatment of forest soil on germination of buried seed. Australian Journal of Botany 28, 567-571. doi:10.1071/ BT9800567

Warr SJ, Thompson K, Kent M (1993) Seed banks as a neglected area of biogeographic research - a review of literature and sampling techniques. Progress in Physical Geography 17, 329-347. doi:10.1177/ 030913339301700303

Wilke B-M (2005) Determination of chemical and physical soil properties. In 'Monitoring and assessing soil bioremediation'. (Ed. R Margesin) pp. 47-95. (Springer: Berlin)

Wills TJ, Read J (2007) Soil seed bank dynamics in post-fire heathland succession in south-eastern Australia. Plant Ecology 190, 1-12. doi:10.1007/S11258-006-9186-4

WorldClim (2013) Data for current conditions ( 1950-2000). Available at http://worldclim.org/current [Verified 23 July 2015]

Zammit CA, Zedler PH (1988) The influence of dominant shrubs, fire, and time since fire on soil seed banks in Mixed Chaparral. Vegetatio 75, 175-187.

Zuur A, Ieno EN, Walker N, Saveliev AA, Smith GM (Eds) (2009) 'Mixed Effects Models and Extensions in Ecology with R.' (Springer Science \& Business Media: New York, NY) 


\section{University Library}

\section{- M M N E R VA A gateway to Melbourne's research publications}

Minerva Access is the Institutional Repository of The University of Melbourne

Author/s:

Chick, MP;Cohn, JS;Nitschke, CR;York, A

Title:

Lack of soil seedbank change with time since fire: relevance to seed supply after prescribed burns

Date:

2016-01-01

\section{Citation:}

Chick, M. P., Cohn, J. S., Nitschke, C. R. \& York, A. (2016). Lack of soil seedbank change with time since fire: relevance to seed supply after prescribed burns. INTERNATIONAL JOURNAL OF WILDLAND FIRE, 25 (8), pp.849-860. https://doi.org/10.1071/WF15013.

Persistent Link:

http://hdl.handle.net/11343/115264 